\title{
GAMBARAN FAKTOR - FAKTOR PENYEBAB MASALAH BERAT BADAN (OVERWEIGHT) ATLET PENCAK SILAT PADA MASA KOMPETISI
}

\author{
Ari Faizal \\ Faisal Kusuma Hadi
}

\section{Program Studi D-III Ilmu Kepelatihan Olahraga, Akademi Olahraga Prestasi Nasional Program Studi Pendidikan Olahraga Universitas Muhammadiyah Jember}

\author{
Ari.faizal@akornas.ac.id \\ Kusumafaisal@rocketmail.com
}

\begin{abstract}
ABSTRAK
Penelitian ini bertujuan untuk mengetahui faktor-faktor yang menjadi penyebab permasalahan berat badan (overweight) atlet Pencak Silat pada masa kompetisi. Penelitian ini dilaksanakan pada bulan November 2018, di Gelanggang Olahraga Ragunan, Jakarta Selatan. Metode ini menggunakan metode survey angket dan wawancara serta menggunakan teknik purvosive sampling. Populasi pada penelitian ini adalah atlet putra dan putri PPLP DKI dan Ragunan, sedangkan sampel dalam penelitian ini adalah atlet putera dan puteri yang mengalami masalah berat badan pada masa kompetisi.

Hasil analisis data keseluruhan menunjukan bahwa gambaran faktor-faktor penyebab masalah berat badan padatnya frekuensi pertandingan dalam setahun sekitar 84,73\%, mengkonsumsi makanan dan minuman yang manis sekitar 84,6 \%, mengkonsumsi makanan berlemak dan bersantan sekitar $83,33 \%$, kepentingan pelatih yang ingin menentukan sendiri kelas bagi atletnya sekitar $81,76 \%$, rendahnya disiplin atlet dalam menjaga berat badan sekitar $72,54 \%$, kurangnya aplikasi pengetahuan pelatih tentang ilmu gizi dan fisiologi olahraga sekitar $29,75 \%$, kurangnya perhatian pelatih dalam mengontrol berat badan sekitar 23,25\%. Saran dalam penelitian ini yaitu pelatih dan pengurus harus mempunyai tujuan utama perihal target yang ingin dicapai, atlet harus bisa mengontrol pola makan, penentuan kelas tanding harus ditentukan oleh atlet sendiri sesuai dengan kondisinya, memasuki masa persiapan umum berat badan atlet harus dalam kriteria ideal, perlunya pengetahuan tentang ilmu gizi dan fisiologi olahraga, pelatih tidak boleh memaksakan atlet untuk mengikuti kelas tanding yang tidak sesuai dengan kondisi atlet, penurunan berat badan dapat menggunakan metode diet rendah beberapa hari menjelang pertandingan.
\end{abstract}

\section{Kata Kunci: Berat Badan, Atlet, Pencak Silat, Kompetisi}

\section{PENDAHULUAN}

Dalam menjalani hidup sehari-hari kita sebaiknya selalu mengedepankan kesehatan tubuh dan jiwa karena sehat itu nikmat yang tak ternilai harganya dan ada juga pepatah yang mengatakan bahwa seseorang tidak akan menghargai kesehatannya sendiri di saat masih sehat, oleh karena itu untuk memperoleh tubuh dan jiwa yang sehat perlu adanya pengaturan pola hidup yang sehat, seperti pengaturan pola makan dan gizi yang seimbang serta perlunya aktivitas olahraga yang rutin.

Olahraga dalam pencapaian prestasi
harus didukung oleh banyak faktor di
antaranya pemilihan bakat yang
disesuaikaan dengan karakter cabang
olahraga, kondisi fisik yang bagus,
kecerdasan yang mendukung tekhnik dan
taktik yang bagus, gizi yang adekuat
(seimbang), mental juara yang harus
tertanam pada diri atlet, serta pelatih yang
berpengalaman dan mengerti tentang ilmu
kelohragaan. Kondisi fisik yang baik
mempunyai peranan sangat penting dalam
pencapaian prestasi yang maksimal selain


dari faktor-faktor yang telah disebutkan di atas.

Untuk mendapatkan kondisi fisik yang prima harus ditunjang dari kondisi antropometri tubuh yang baik sesuai dangan karakter cabang olahraga masing-masing, pemberian program latihan yang tepat dan asupan gizi yang adekuat. Kebutuhan gizi pada olahraga ada kalanya tidak seimbang antara diet yang tersedia dengan yang diperlukan. Aibatnya, dampak dari ketidakseimbangan gizi ini dapat berdampak pada keadaan berat badan atlet yang tidak sesuai dengan yang diinginkan. Lebih-lebih cabang olahraga yang mempunyai klasifikasi kelas berdasarkan berat badan seperti cabang olahraga pencak silat, taekwondo, gulat, dayung, tinju, yudo, karate, dan sebagainya.

Pengaturan berat badan menjadi sangat penting dan perlu penanganan yang serius, baik dari pengetahuan program latihan maupun penanganan nutrisi sehingga terciptannya prestasi olahraga yang maksimal. Prestasi olahraga dapat ditingkatkan dengan diet yang benar disertai dengan program latihan yang tepat. Prestasi tertinggi tidak akan tercapai apabila selama latihan sampai pada saat pertandingan, pemberian gizi secara optimal tidak diatur dan dipelihara. Akibat latihan yang intensif, pemberian gizi yang adekuat merupakan bagian yang terpenting dalam menunjang prestasi atlet yang maksimal.

Pengetahuan gizi harus dimiliki oleh para atlet dan pelatih, khususnya tentang pengaturan makanan untuk atlet sangat bermanfaat, karena memberikan beberapa keuntungan bagi atlet tersebut antara lain memberikan pengetahuan tentang makanan yang dapat mencapai atau mempertahankan kondisi tubuh yang telah diperoleh dalam latihan, memberikan makanan yang dapat menyediakan energi yang diperlukan untuk melakukan aktivitas fisik dan olahraga, menentukan bentuk makanan dan frekuensi makan yang tepat pada waktu latihan intensif sebelum, selama dan sesudah pertandingan, menggunakan prinsip gizi dalam menurunkan dan menaikkan berat badan sesuai yang diinginkan, menggunakan prinsip gizi untuk mengembangkan atau membuat rencana diet individu sesuai dengan aturan tubuh, keadaan fisiologi dan metabolismenya.

Akan tetap, fakta yang ada di lapangan sangatlah sulit untuk mengontrol pola makan atlet yang mengarah pada asupan gizi yang adekuat, jika tidak ada pemusatan latihan dimana pola makan dan pola latihan sudah diatur sedemikian rupa yang mengarah pada pencapaian prestasi yang maksimal. Tetapi tidak selesai di sini saja permasalahannya, walaupun pola makan atlet sudah diatur, atlet berkelit dengan melanggar pola makan yang sudah diatur dengan jajan diluar pola makan yang sudah diatur dengan alasan tidak sesuai selera. Akibatnya, akan timbul permasalahan berat badan yang akan berakibat pada tidak maksimalnya prestasi yang dicapai.

Permasalahan berat badan inilah yang sering terjadi pada atlet-atlet cabang olahraga bela diri yang sebagian menggunakan klasifikasi berat badan. Permasalahan berat badan ini harus mendapat perhatian yang serius dari para pelatih, serta kesadaran atlet yang memiliki kelebihan berat badan karena akan sangat berpengaruh terhadap prestasi. Permasalahan ini juga yang saya pernah alami hampir di setiap kejuaraan pencak silat yang saya ikuti, sehingga saya tertarik untuk meneliti permasalahan ini.

Kasus yang terjadi di beberapa event terakhir pada cabang olahraga Pencak Silat, hampir mayoritas atlet pada cabang beladiri ini sibuk untuk menurunkan berat badan dengan cara jogging, memakai jaket sauna, dan ditempat yang panas. Sebagian besar atlet yang menurunkan berat badan itu adalah mahasiswa yang berasal dari Fakultas Ilmu Keolahragaan Universitas Negeri Jakarta, yang pada dasarnya mengerti tentang teori bagaimana cara menurunkan berat badan yang aman. Tetapi memang pada dasarnya praktek tidak semudah teori, kita tahu penurunan berat badan yang aman harus diatur berdasarkan kalori yang masuk dan kalori yang keluar, pada orang biasa dapat dilakukan penurunan berat sampai $1 \mathrm{~kg}$ per minggu, tapi jika pada atlet dapat dimodifikasi 
hingga $2 \mathrm{~kg}$ per minggu, itu pun dengan program diet yang sehat dan ketat.

Jika proses penurunan berat badan itu dilakukan terlalu cepat maka akan berdampak tidak baik bagi kondisi fisiologi atlet, hal ini dikarenakan bukannya lemak yang di bakar, tetapi konsentrasi cairan didalam tubuh kita yang akan berkurang. Jika konsentarasi cairan yang berkurang maka akan berdampak buruk bagi sistem

\section{TAHAP KOMPETISI}

Tujuan dari tahap kompetisi yaitu menggali potensi atlet untuk berkembang seoptimal mungkin, baik potensi fisik, teknik, taktik, dan mental, karena aspek ini merupakan komponen utama untuk meraih kemenangan, sehingga prestasi atlet dapat mencapai puncaknya pada pertandingan utama yang dijadikan target selama ini (Hari H). Atlet sudah dalam kondisi siap tempur, sehingga lebih percaya diri dan memiliki motivasi yang tinggi untuk mencapai kemenangan. Karakteristik latihan di tahap kompetisi diantaranya, (1) Intensitas latihan naik tajam yaitu mencapai 90-100\%, (2) Volume latihan menurun tajam, (3) Bobot volume latihan: Taktik sekitar $70 \%$, Teknik sekitar $10 \%$, Mental sekitar $15 \%$, Fisik sekitar $5 \%$, (4) Sekitar 1 minggu sebelum "Hari $\mathrm{H}$ " adalah tahap unloading (pengurangan beban latihan), (5) 2 hari menjelang "Hari $\mathrm{H}$ " latihan ringan, waktu singkat, dan intensitas rendah.

\section{PENCAK SILAT}

Soetardjonegoro dari perguruan Phasaja Mataram di Yogyakarta mendefinisikan Pencak Silat sebagai berikut : Pencak adalah gerakan serang bela, yang teratur menurut sistem, waktu, tempat dan iklim dengan selalu menjaga kehormatan masing-masing secara kesatria, tidak mau melukai perasaan. Jadi Pencak lebih menunjukan dari segi lahiriah. Silat adalah gerak bela serang yang erat hubungannya dengan rohani, sehingga menghidup suburkan naluri, menggerakan hati nurani manusia, langsung menyerah kepada Tuhan Yang Maha Esa.

Dewasa ini istilah pencak silat mengandung unsur-unsur olahraga, seni, bela diri dan kebatinan. Definisi Pencak fisiologi tubuh yang akhirnya berdampak pada prestasi yang tidak maksimal. Oleh karena itu saya tertarik mendalami faktorfaktor penyebab masalah kelebihan berat badan pada atlet cabang olahraga Pencak Silat pada masa kompetisi. Untuk diteruskan sebagai bahan permasalahan yang akan dilanjutkan ke tingkat penelitian lebih lanjut.

Silat selengkapnya yang pernah di buat Pengurus Besar Ikatan Pencak Silat Indonesia tahun 1975 adalah sebagai berikut : Pencak silat dalah hasil budaya manusia untuk membela atau mempertahankan eksistensi (kemandirian) dan integritasnya (manunggalnya).

Sistem energi yang digunakan dalam setiap cabang olahraga berfungsi untuk menentukan jenis latihan yang dilakukan. Selama ini belum ada penelitian yang mengungkap masalah predominan sistem energi yang digunakan selama dalam pertandingan pencak silat, khususnya untuk kategori tanding. Untuk menentukan persentase predominan sistem energi yang digunakan dalam pencak silat tanding, perlu mempertimbangkan beberapa hal antara lain: lama waktu pertandingan, macam gerak, irama gerak, waktu recovery, dan interval. Lama waktu pertandingan dalam pencak silat dilakukan dalam tiga ronde, dengan waktu istirahat antar ronde 1 menit. Tiap ronde dalam pertandingan pencak silat memerlukan waktu 2 menit bersih. Artinya, ketika wasit menghentikan pertandingan karena terjadi insiden, maka waktu tersebut tidak termasuk waktu bertanding. Dengan demikian waktu pertandingan adalah total waktu efektif yang di gunakan selama pertandingan berlangsung, yaitu diawali dari aba-aba mulai sampai dengan aba-aba berhenti.

Oleh karena pada saat melakukan fight (waktu kerja) waktu yang digunakan rata-rata 3 detik, maka energi yang digunakan selama melakukan fight (waktu kerja) lebih dominan menggunakan sistem energi anaerobik alaktik (ATP-PC). Namun demikian dalam olahraga pencak silat perlu dilandasi dengan kemampuan kapasitas aerobik yang baik,karena kemampuan aerobik yang baik merupakan dasar untuk 
mendapatkan kemampuan an-aerobik yang baik.

\section{ATLET}

Mempersiapakan seorang atlet perlu ditempuh suatu siklus di dalam kehidupan maupun dalam musim berlatih. Berkenaan dengan faktor kejiwaan yang demikian seorang atlet daerah atau atlet klub olahraga yang terpilih menjadi atlet Nasional dapat digolongkan ke dalam salah satu dari tiga tipe berikut (1) Atlet yang memang menggemari olahraga atau yang telah terbiasa dengan dasar-dasar olahraga tersebut sebelum menjalani latihan terpadu. Atlet semacam itu dapat dikatakan bermotivasi secara intrinsik yaitu dari dalam jiwanya sendri, menyadari manfaat olahraga dan makna menjadi juara, (2) Atlet yang terlatih hanya ada dorongan dari luar dirinya, misalnya dari pelatih. Walaupun atlet semacam itu menunjukan tanggapan atau respon yang positif terhadap petunjuk latihan, namun karena bergantung faktor dari luar dirinya maka seringkali terjadi kesenjangan antara petunjuk yang diterima dengan kondisi fisik dan mental atlet yang bersangkutan, (3) Atlet yang memiliki motivasi dari dalam dirinya secara cukup memadai sering kurang petunjuk dari pelatih, bersikap kurang positif terhadap pembinaan.

Dari teori di atas peneliti dapat menyimpulkan bahwa atlet adalah seseorang yang sungguh-sungguh dalam berolahraga untuk mencapai prestasi yang maksimal dengan melatih komponen kebugaran jasmaninya. Setiap atlet punya kebutuhan akan cita-cita yang ingin dicapai. Berdasarkan keterangan di atas bahwa seorang atlet harus mempunyai motivasi dan sungguh-sungguh dalam berlatih agar terciptanya prestasi yang setinggi-tingginya.

Faktor adalah suatu hal (kedaan, peristiwa, dan sebagainya) yang ikut menyebabkan (mempengaruhi) terjadinya sesuatu. Sedangkan Penyebab adalah hal yang menyebabkan sesuatu. Dari pengertian faktor dan penyebab dapat saya tarik satu kesimpulan hakekat dari faktor penyebab yaitu suatu hal, baik keadaan ataupun peristiwa yang dapat dan ikut menyebabkan terjadinya suatu hal yang baru.

\section{BERAT BADAN}

Bobot tubuh atau berat badan adalah ukuran yang terlazim digunakan untuk menilai status gizi manusia. Setiap manusia memiliki berat badan/bobot tubuh yang berbeda-beda hal ini disebabkan oleh beberapa faktor penyusun tubuh seperti : (1) Cairan tubuh sebanyak $60 \%$, (2) Protein sebanyak $18 \%$, (3) Lemak sebanyak $15 \%$, (4) Mineral sebanyak $7 \%$

\section{CAIRAN TUBUH}

Air merupakan bagian terbesar dari komposisi tubuh, bayi dan anak-anak kecil terdiri dari $80 \%$ air, orang dewasa $60-70$ $\%$, dan manula 50 - $60 \%$. Hampir semua reaksi di dalam tubuh manusia memerlukan cairan agar metabolisme tubuh berjalan dengan baik, dibutuhkan masukan cairan setiap hari untuk menggantikan cairan yang hilang.

Tabel 1. Proporsi Cairan Tubuh Berdasarkan Usia

\begin{tabular}{|c|c|c|c|c|c|}
\hline \multicolumn{2}{|c|}{ Jenis } & B & 3 & Dew & Lan \\
\hline & & B & bl & & \\
\hline \multirow{2}{*}{\multicolumn{2}{|c|}{ Cairan intraseluler }} & $\mathrm{L}$ & & & \\
\hline & & 40 & 40 & $40 \%$ & 27 \\
\hline \multirow{4}{*}{$\begin{array}{c}\text { Cairan } \\
\text { ekstras } \\
\text { eluler }\end{array}$} & & 5 & 5 & $50 \%$ & $7 \%$ \\
\hline & $\begin{array}{c}\text { (intravas } \\
\text { kuler) }\end{array}$ & $\%$ & $\%$ & & \\
\hline & Intersteti & 35 & 25 & $15 \%$ & 18 \\
\hline & el & $\%$ & $\%$ & & $\%$ \\
\hline \multirow{2}{*}{\multicolumn{2}{|c|}{ Total cairan }} & 80 & 70 & $60 \%$ & 52 \\
\hline & & $\%$ & $\%$ & & $\%$ \\
\hline
\end{tabular}

Ket: BBL (bayi baru lahir)

Faktor yang mempengaruhi jumlah cairan tubuh adalah umur, jenis kelamin, dan kandungan lemak dalam tubuh. Secara umum orang yang lebih muda mempunyai prosentase cairan tubuh yang lebih tinggi dibanding dengan orang yang lebih tua, dan pria secara proporsional mempunyai lebih banyak cairan tubuh dibanding dengan wanita. Orang yang lebih gemuk mempunyai jumlah cairan yang lebih sedikit dibandingkan dengan orang yang lebih kurus, karena sel lemak mengandung sedikit air. 
Air tidak mengandung energi, tetapi sangat penting dalam kehidupan sehari-hari. Kebutuhan tubuh manusia akan air dalam sehari sesuai dengan banyaknya air yang keluar atau yang hilang dari tubuh. Banyaknya air yang dibutuhkan kurang lebih $2500 \mathrm{ml}$ sehari. Saat berolahraga kebutuhan air tentu akan lebih banyak dibanding dalam keadaan istirahat, karena saat berolahraga suhu tubuh meningkat dan tubuh menjadi panas. Tubuh yang panas berusaha untuk menjadi dingin dengan cara berkeringat, banyaknya keringat yang keluar tergantung dari ukuran tubuh, jenis olahraga, intensitas olahraga, lamanya olahraga, cuaca dan kelembaban lingkungan, serta jenis pakaian atlet. Keringat yang keluar saat olahraga sebagian besar terdiri atas air, namun keringat juga mengandung elektrolit. Perubahan status cairan tubuh saat berolahraga disebabkan oleh peningkatan produksi keringat dan asupan cairan ke dalam tubuh yang sedikit.

Defisit air sebanyak 1\% dari berat badan yang keluar dalam bentuk keringat saat berolahraga terbukti mengurangi toleransi tubuh terhadap olahraga. Sedangkan, defisit air 3\% sampai dengan $10 \%$ dari berat badan selama mengikuti olahraga menyebabkan penurunan prestasi olahraga, meningkatkan risiko cedera, serta berbahaya untuk atlet.

Tabel 2. Hubungan Dehidrasi Air Tubuh Dengan Kinerja Fisik Dan Kesehatan

\begin{tabular}{cl}
\hline $\begin{array}{c}\text { Prosentase } \\
(\%)\end{array}$ & \multicolumn{2}{c}{ Dampak } \\
\hline $1 \%$ & $\begin{array}{l}\text { Haus, suhu tubuh mulai } \\
\text { meningkat,performance } \\
\text { mulai turun }\end{array}$ \\
\hline $2 \%$ & $\begin{array}{l}\text { Sangat haus, suhu tubuh } \\
\text { meningkat, performance } \\
\text { menurun }\end{array}$ \\
\hline $3 \%$ & Idem dan semakin parah \\
\hline $4 \%$ & $\begin{array}{l}\text { Physical performance } \\
\text { menurun 20-30 \% }\end{array}$ \\
\hline $5 \%$ & $\begin{array}{l}\text { Sakit kepala,rasa melayang, } \\
\text { lelah }\end{array}$ \\
\hline $6 \%$ & $\begin{array}{l}\text { Lemah, keram,gangguan } \\
\text { serius thermoregulation. }\end{array}$ \\
\hline $7 \%$ & Pingsan \\
\hline Pemberian cairan pada atlet bertujuan \\
mencegah dehidrasi dan untuk
\end{tabular}

mempertahankan keseimbangan cairan tubuh. Nasihat yang paling baik saat berolahraga untuk mencegah kekurangan cairan adalah minum air sebelum, selama dan setelah berolahraga. Minum air jangan menunggu sampai rasa haus timbul. Oleh karena, rasa haus tidak cukup baik sebagai indikator keinginan untuk minum. Keinginan minum air lebih banyak dan lebih sering karena kebiasaan, bukan karena adaptasi fisiologis. Rasa haus baru timbul apabila tubuh telah mengalami kekurangan air (dehidrasi). Dehidrasi ringan dapat mengganggu prestasi atlet, sedangkan dehidrasi berat dapat terjadi heatstroke atau bahkan kematian

Penggantian air yang seimbang selama berolahraga sangat penting untuk memelihara penampilan yang optimal dan memelihara kesehatan. Minumlah air 30-60 menit sebelum bertanding sebanyak 150 $250 \mathrm{ml}$. Air dingin kira-kira $10^{\circ} \mathrm{C}$ lebih baik dari pada air hangat. Oleh karena air dingin lebih cepat diserap oleh usus, sehingga waktu pengosongan lambung lebih cepat. Pemberian air dalam jumlah yang sama dianjurkan pada atlet saat beristirahat diantara pertandingan. Selama bertanding, atlet dianjurkan minum secara teratur setiap 10-15 menit sebanyak 150-250 ml air dingin.

Fungsi cairan tubuh antara lain: (1) Mengatur suhu tubuh Bila kekurangan air, suhu tubuh akan menjadi panas dan naik, (2) Melancarkan peredaran darahJika tubuh kita kurang cairan, maka darah akan mengental. Hal ini disebabkan cairan dalam darah tersedot untuk kebutuhan dalam tubuh. Proses tersebut akan berpengaruh pada kinerja otak dan jantung, (3) Membuang racun dan sisa makanan Tersedianya cairan tubuh yang cukup dapat membantu mengeluarkan racun dalam tubuh. Air membersihkan racun dalam tubuh melalui keringat, air seni, dan pernafasan, (4) Air sangat penting untuk mengatur struktur dan fungsi kulit. Kecukupan air dalam tubuh berguna untuk menjaga kelembaban, kelembutan, dan elastisitas kulit akibat pengaruh suhu udara dari luar tubuh, (5) Peran air dalam proses pencernaan untuk mengangkut nutrisi dan oksigen melalui darah untuk segera dikirim 
ke sel-sel tubuh. Konsumsi air yang cukup akan membantu kerja sistem pencernaan di dalam usus besar karena gerakan usus menjadi lebih lancar, sehingga feses pun keluar dengan lancar, (6) Paru-paru memerlukan air untuk pernafasan karena paru-paru harus basah dalam bekerja memasukkan oksigen ke sel tubuh dan memompa karbondioksida keluar tubuh. Hal ini dapat dilihat apabila kita menghembuskan nafas ke kaca, maka akan terlihat cairan berupa embun dari nafas yang dihembuskan pada kaca, (7) Cairan tubuh melindungi dan melumasi gerakan pada sendi dan otot. Otot tubuh akan mengempis apabila tubuh kekurangan cairan. Oleh sebab itu, perlu minum air dengan cukup selama beraktivitas untuk meminimalisir resiko kejang otot dan kelelahan, (8) Air mendukung proses pemulihan ketika sakit karena asupan air yang memadai berfungsi untuk menggantikan cairan tubuh yang terbuang.

Dari uraian di atas kita telah ketahui manfaat dari cairan yang ada dalam tubuh kita, bila kita kekurangan zat cair maka fungsi fisiologis tubuh kita akan terganggu akibat bila tubuh kita kekurangan zat cair, di antaranya adalah dehidrasi. Dehidrasi adalah keadaan dimana tubuh kehilangan cairan elektrolit yang sangat dibutuhkan organ-organ tubuh untuk bisa menjalankan fungsinya dengan baik. Saat dehidrasi, tubuh dengan terpaksa menyedot cairan baik dari darah maupun organ-organ tubuh lainnya.

\section{PROTEIN}

Protein adalah bagian dari semua sel hidup dan merupakan bagian terbesar tubuh sesudah air. Seperlima bagian tubuh adalah protein, separuhnya ada didalam otot, seperlima ada didalam tulang dan tulang rawan, sepersepuluh ada didalam kulit, dan selebihnya ada didalam jaringan lain dan cairan tubuh. Protein mempunyai fungsi khas yang tidak dapat digantikan oleh zat gizi lain, yaitu membangun dan memelihara sel- sel dan jaringan tubuh.

Protein diperlukan terutama sebagai zat pembangun, protein dapat dijadikan sumber energi apabila energi yang berasal dari karbohidrat dan lemak tidak mencukupi. Walaupun protein merupakan zat pembangun jaringan tubuh namun tidak berarti makin tinggi konsumsi protein makin besar pembentukan otot. Pembentukan masa otot dan kekuatanya di tentukan oleh latihan yang terprogram dengan baik yang harus di tunjang oleh makanan yang cukup. Pada prakteknya atlet harus mengutamakan makanan lebih banyak hidratarang dari pada protein.

\section{Tabel 3. Proporsi Protein Untuk Jumlah Energi Total Sehari}

Jumlah energi/ hari $\%$ protein dari jumlah Kalori

total energi perhari

\begin{tabular}{cc}
\hline 2500 & $15 \%$ \\
$3000-4000$ & $13-14 \%$ \\
$4500-5000$ & $10-12 \%$ \\
\hline \multicolumn{2}{c}{ Fungsi protein di dalam tubuh kita }
\end{tabular}
sangat banyak, bahkan banyak dari proses pertumbuhan tubuh manusia dipengaruhi oleh protein yang terkandung di dalam tubuh kita, di antaranya: (1) Sebagai enzim, (2) Alat pengangkut dan penyimpan, (3) Penunjang mekanis, (4) Media perambatan impuls syaraf, (5) Pengendalian pertumbuhan. Kekurangan Protein bisa berakibat fatal (a) Kerontokan rambut (Rambut terdiri dari 97-100\% dari ProteinKeratin), (b) Yang paling buruk ada yang disebut dengan Kwasiorkor, penyakit kekurangan protein. Biasanya pada anakanak kecil yang menderitanya, dapat dilihat dari yang namanya busung lapar, yang disebabkan oleh filtrasi air di dalam pembuluh darah sehingga menimbulkan odem.

\section{LEMAK}

Merupakan salah satu penyusun terbesar komposisi tubuh setelah cairan dan protein, kurang lebih $15 \%$ dari tubuh disusun oleh lemak, keberadaannya dalam tubuh dianggap sebagai sistem biologik terutama untuk cadangan energi dalam sel dan sebagai komponen membran sel. Selain itu berfungsi juga sebagai pengangkut vitamin-vitamin yang larut dalam lemak yaitu Vitamin A, Vitamin D, Vitamin E dan Vitamin K. Secara umum dapat dikatakan 
bahwa lemak memenuhi fungsi dasar bagi manusia, yaitu (1) Menjadi cadangan energi dalam bentuk sel lemak. 1 gram lemak menghasilkan 39.06 kjoule atau 9,3 kcal, (2) Lemak mempunyai fungsi selular dan komponen struktural pada membran sel yang berkaitan dengan karbohidrat dan protein demi menjalankan aliran air, ion dan molekul lain, keluar dan masuk ke dalam sel, (3)Menopang fungsi senyawa organik sebagai penghantar sinyal, seperti pada prostaglandin dan steroid hormon dan kelenjar empedu, Lemak juga merupakan sarana sirkulasi energi di dalam tubuh dan komponen utama yang membentuk membran semua jenis sel.

\section{MINERAL}

Mineral merupakan suatu zat organik yang terdapat dalam kehidupan alam maupun dalam makhluk hidup. Di alam, mineral merupakan unsur penting pada tanah, bebatuan, air, dan udara. Sedangkan pada tubuh makhluk hidup sendiri mineral merupakan salah satu komponen penyusun tubuh. $4-5 \%$ berat badan kita terdiri atas mineral, sekitar 50\% mineral tubuh terdiri atas kalsium, 25\% fosfor, dan $25 \%$ lainnya terdiri atas mineral lain Tubuh memerlukan mineral dari luar karena fungsinya yang penting untuk kelangsungan proses metabolisme.

Mineral dibagi dalam 3 kelompok berdasarkan jumlah yang diperlukan oleh tubuh, yaitu: (1) Makromineral (kalsium, fosfor, magnesium, natrium, kalium, klorida, dan sulfur), (2) Mikromineral (zat besi, seng, tembaga, dan florida), dan Ultrace mineral diperlukan dalam jumlah yang sangat kecil (yodium, selenium, mangan, kromium, molibdenim, boron, dan kobalt). Fungsi mineral secara umum antara lain (a) Komponen penting senyawa dalam tubuh seperti kalsium dan fosfor sebagai penyusun struktur tulang dan gigi (b) Kofaktor atau metaloenzim dalam reaksi biologis (c) Fasilitator penyerapan dan transport zat gizi (d) Menjaga kesimbangan asam basa tubuh (e) Menjaga keseimbangan cairan tubuh (f) Penghantar impuls saraf (g) Regulasi kontraksi otot.Dari teori-teori yang telah dijelaskan, dapat ditarik suatu kesimpulan bahwa berat badan atau bobot tubuh manusia berbeda-beda karena di pengaruhi oleh komposisi penyusunnya seperti cairan $60 \%$, protein $18 \%$, lemak 15 $\%$, dan mineral $7 \%$. Selain itu dari pola makan dan aktivitas sehari - hari amat menentukan berat badan seseorang.

Penelitian dilakukan oleh Rankin (2002) mengenai cara cara penurunan berat badan yang kurang tepat membuktikan bahwa cara-cara seperti di atas ternyata bisa berakibat buruk karena dapat menyebabkan gangguan dalam tubuh seperti dehidrasi, kehilangan massa otot, penurunan tingkat kecerdasan, dan juga penurunan performa di saat latihan. Penggunaan suplemen atau obat-obatan penurun berat badan secara sembarangan ternyata juga akan mengakibatkan stimulasi berlebihan pada sistem peredaran darah misalnya hipertensi dan stroke.

\section{KERANGKA BERFIKIR}

Jenis Olahraga yang membagi kelas berdasarkan berat badan adalah pencak silat, taekwondo, tinju, gulat, angkat berat, dan dayung. Pada Olahraga jenis ini terdapat 2 tradisi yang tidak menguntungkan. Pertama adalah keinginan untuk bertanding di kelas dengan berat badan yang lebih rendah daripada berat badan normal selama latihan. Secara teori, berat badan yang lebih tinggi lebih menguntungkan melawan atlet dengan berat badan yang lebih rendah.

Tradisi kedua adalah keinginan untuk menurunkan kelebihan berat badan secara cepat yaitu 3 - $6 \mathrm{~kg}$ dalam beberapa hari (overweight). Hal tersebut mengakibatkan digunakannya berbagai tekhnik yang drastis seperti dehidrasi dengan sauna atau pakaian dari plastik, puasa, penggunaan obat diuretik dan pencahar. Secara fisiologis menurunkan berat badan dengan cara seperti ini sangatlah tidak baik. Teknik ini mungkin efektif namun atlet akan kehilangan cairan tubuh, simpanan glikogen otot, sehingga status kesehatan dan penampilan atlet terganggu. Walaupun atlet makan setelah itu, kerusakan yang terjadi tidak dapat diperbaiki dengan cepat.

Waktu yang ideal dalam proses menurunkan berat badan khususnya pada cabang yang memiliki klasifikasi berat 
badan yaitu pada masa persiapan umum dalam periodesasi latihan, pada umumnya waktu untuk menurunkan berat badan 0,5 $1 \mathrm{~kg}$ per minggunya, itu bisa di dapat dengan cara pengaturan pola makan dan latihan, tetapi dalam dunia olahraga dapat dilakukan hingga $2 \mathrm{~kg}$ per minggunya, itupun harus melakukan diet yang ketat. Dalam penelitian ini, peneliti lebih

Di sinilah permasalahan terjadi, jika seorang atlet yang mengalami overweight harus melaksanakan pertandingan sebanyak lima kali, maka ia harus menyiapkan energi yang ekstra untuk menjalani semua pertandingan tersebut, sedangkan di sisi lain asupan energi kepada atlet ini pastilah kurang dari energi yang akan ia keluarkan, oleh karena itu para pengurus, pelatih, ahli gizi, dan atlet tersebut mencari solusi yang terbaik agar permasalahan ini tidak menghambat pencapaian prestasi yang maksimal. Sebelum melangkah lebih Jauh dalam permasalahan ini peneliti berinisiatif mencari penyebab permasalahan berat badan pada atlet Pencak silat terutama pada masa kompetisi, karena disinilah permasalahanya mulai nampak terlihat dimana atlet melakukan penurunan berat badan diluar aturan, sebagai langkah awal mencari solusinya.

\section{METODE PENELITIAN}

Penelitian ini dilakukan dengan menggunakan metode Deskriptif dengan teknik survei angket dan wawancara. Teknik survei angket ini berupa teknik pengambilan data. Data yang di ambil sesuai dengan pengalaman atau kejadian yang pernah dialami atlet yang diambil sebagai sampel. Penelitian ini dilakukan di Gelanggang Olahraga Ragunan Jakarta Selatan, Jakarta tanggal 23 November 2011. Populasi dalam penelitian ini adalah keseluruhan atlet Tanding putera dan puteri yang tergabung dalam PPLP DKI Jakarta dan Ragunan (23 orang). Dalam penelitian ini menggunakan Purposive Sampling dengan maksud dan tujuan tertentu. Sampel dalam penelitian ini adalah atlet tanding putera dan puteri yang mengalami permasalahan berat badan (overweight) pada masa kompetisi.

\section{HASIL PENELITIAN}

Untuk mengetahui hasil dari data penelitian yang telah dilaksanakan maka melakukan langkah selanjutnya peneliti melakukan analisis data dan pengolahan data terhadap hasil penelitian berupa angket yang telah di isi oleh responden. Setelah menghitung skor rata-rata tiap butir pernyataan berdasarkan hasil penelitian jawaban responden, kemudian dilakukan interpretasi hasil jawaban dari tiap butir pernyataan.

Tabel 5. Interpretasi Hasil Analisis Data setiap Butir Pernyataan

\begin{tabular}{|c|c|c|}
\hline $\begin{array}{l}\mathbf{N} \\
\mathbf{O}\end{array}$ & $\begin{array}{c}\text { Hasil } \\
\text { Anali } \\
\text { sis } \\
\text { Data }\end{array}$ & Interpretasi \\
\hline 1 & $\begin{array}{l}\mathrm{SS}= \\
63 \% \\
\mathrm{~S}= \\
38 \% \\
\mathrm{RR}= \\
0 \% \\
\mathrm{TS}= \\
0 \% \\
\mathrm{STS} \\
=0 \%\end{array}$ & $\begin{array}{l}\text { Sebanyak } 100 \% \text { atlet } \\
\text { mengatakan YA bahwa } \\
\text { makanan yang rendah kalori } \\
\text { dan gizi seimbang merupakan } \\
\text { menu yang baik untuk atlet } \\
\text { yang overweight/menurunkan } \\
\text { berat badan,0 \% RAGU- } \\
\text { RAGU, dan } 0 \% \text { TIDAK. }\end{array}$ \\
\hline 2 & $\begin{array}{l}\mathrm{SS}= \\
20 \% \\
\mathrm{~S}= \\
48 \% \\
\mathrm{RR}= \\
24 \% \\
\mathrm{TS}= \\
8 \% \\
\mathrm{STS} \\
=0 \%\end{array}$ & $\begin{array}{l}\text { Sebanyak } 68 \% \text { atlet } \\
\text { mengatakan YA bahwa dirinya } \\
\text { melakukan metode } \\
\text { menurunkan berat badan } 1 \\
\text { bulan menjelang pertandingan, } \\
24 \% \text { RAGU-RAGU,dan } 8 \% \\
\text { TIDAK. }\end{array}$ \\
\hline 3 & $\begin{array}{l}\mathrm{SS}= \\
0 \% \\
\mathrm{~S}= \\
80 \% \\
\mathrm{RR}= \\
20 \% \\
\mathrm{TS} \\
=\% \\
\mathrm{STS} \\
=0 \%\end{array}$ & $\begin{array}{l}\text { Sebanyak } 80 \% \text { atlet } \\
\text { mengatkan YA bahwa dirinya } \\
\text { melakukan } \\
\text { menurunkan berat badan } 2 \\
\text { minggu } \\
\text { pertandingan, } 20 \% \text { menjelang } \\
\text { RAGU, dan } 0 \% \text { TIDAK. }\end{array}$ \\
\hline 4 & $\begin{array}{l}\mathrm{SS} \\
=0 \% \\
\mathrm{~S}=\end{array}$ & $\begin{array}{l}\text { Sebanyak } 7,7 \quad \% \quad \text { atlet } \\
\text { mengatakan YA bahwa dirinya } \\
\text { ingin bermain di kelas tertentu }\end{array}$ \\
\hline
\end{tabular}




\begin{tabular}{|c|c|c|}
\hline & $\begin{array}{l}7,7 \% \\
\mathrm{RR}= \\
12 \% \\
\mathrm{TS}= \\
62 \% \\
\mathrm{STS}= \\
19 \%\end{array}$ & $\begin{array}{l}\text { walaupun beratnya over, } 12 \% \\
\text { RAGU-RAGU, dan } 62 \% \\
\text { TIDAK }\end{array}$ \\
\hline 5 & $\begin{array}{l}\mathrm{SS}= \\
42 \% \\
\mathrm{~S}= \\
17 \% \\
\mathrm{RR}= \\
25 \% \\
\mathrm{TS}= \\
17 \% \\
\mathrm{STS} \\
=0 \%\end{array}$ & $\begin{array}{l}\text { Sebanyak } 58,32 \% \text { atlet } \\
\text { mengatkan YA bahwa } \\
\text { pelatihnya selalu mengontrol } \\
\text { berat badannya pada saat } \\
\text { melakukan penurunan berat } \\
\text { badan } 25 \% \text { RAGU-RAGU, } \\
\text { dan } 17 \% \text { TIDAK }\end{array}$ \\
\hline 6 & $\begin{array}{l}\mathrm{SS}= \\
20 \% \\
\mathrm{~S}= \\
48 \% \\
\mathrm{RR}= \\
24 \% \\
\mathrm{TS} \\
=8 \% \\
\mathrm{STS} \\
=0 \%\end{array}$ & $\begin{array}{l}\text { Sebanyak } 68 \% \text { atlet } \\
\text { mengatakan YA bahwa } \\
\text { pelatihnya menginginkannya } \\
\text { bermain di kelas tertentu } \\
\text { walaupun beratnya over, } 24 \% \\
\text { RAGU-RAGU, dan } 8 \\
\text { \%TIDAK. }\end{array}$ \\
\hline 7 & $\begin{array}{l}\text { SS } \\
=0 \% \\
\mathrm{~S}= \\
21 \% \\
\mathrm{RR}= \\
47 \% \\
\mathrm{TS}= \\
32 \% \\
\mathrm{STS} \\
=0 \%\end{array}$ & $\begin{array}{l}\text { Sebanyak } 21 \% \text { atlet } \\
\text { mengatakan YA bahwa } \\
\text { pelatihnya selalu mengontrol } \\
\text { pola makannya pada saat } \\
\text { menurunkan berat badan, } \\
\text { 47,36 \% RAGU-RAGU, dan } \\
31,57 \% \text { TIDAK }\end{array}$ \\
\hline 8 & $\begin{array}{l}\mathrm{SS} \\
=0 \% \\
\mathrm{~S}= \\
0 \% \\
\mathrm{RR}= \\
11 \% \\
\mathrm{TS}= \\
71 \% \\
\mathrm{STS} \\
=18 \\
\%\end{array}$ & $\begin{array}{l}\text { Sebanyak } 0 \% \text { atlet } \\
\text { mengatakan YA bahwa } \\
\text { pelatihnya menyarankannya } \\
\text { menkonsumsi obat pencahar } \\
\text { dalam menurunkan berat } \\
\text { badan, } 10,71 \% \text { RAGU- } \\
\text { RAGU, dan } 89,27 \% \text { TIDAK. }\end{array}$ \\
\hline 9 & $\begin{array}{l}\mathrm{SS}= \\
19 \% \\
\mathrm{~S}= \\
74 \%\end{array}$ & $\begin{array}{l}\text { Sebanyak } 92,57 \% \text { atlet } \\
\text { mengatakan YA bahwa } \\
\text { pelatihnya menyarankannya } \\
\text { memakai jaket sauna dalam }\end{array}$ \\
\hline
\end{tabular}

\begin{tabular}{|c|c|c|}
\hline & $\begin{array}{l}\mathrm{RR}= \\
0 \% \\
\mathrm{TS}= \\
7 \% \\
\mathrm{STS} \\
=0 \%\end{array}$ & $\begin{array}{l}\text { menurunkan berata badan, } 0 \% \\
\text { RAGU-RAGU,dan } 7,40 \% \\
\text { TIDAK. }\end{array}$ \\
\hline $\begin{array}{l}1 \\
0\end{array}$ & $\begin{array}{l}\mathrm{SS}= \\
17 \% \\
\mathrm{~S}= \\
83 \% \\
\mathrm{RR}= \\
0 \% \\
\mathrm{TS} \\
=0 \% \\
\mathrm{STS} \\
=0 \%\end{array}$ & $\begin{array}{l}\text { Sebanyak } 100 \% \text { atlet } \\
\text { mengatakan YA bahwa } \\
\text { pelatihnya menyarankan } \\
\text { mengganti makan nasi dengan } \\
\text { buah-buahan pada malam hari, } \\
0 \% \text { RAGU-RAGU, dan } 0 \% \\
\text { TIDAK. }\end{array}$ \\
\hline 1 & $\begin{array}{l}\mathrm{SS} \\
=0 \% \\
\mathrm{~S}= \\
0 \% \\
\mathrm{RR}=2 \\
2 \% \\
\mathrm{TS} \\
=59 \% \\
\mathrm{ST} \\
=18 \%\end{array}$ & $\begin{array}{l}\text { Sebanyak } 0 \% \text { atlet } \\
\text { mengatakan bahwa dirinya } \\
\text { menjalani 1 kali latihan dalam } \\
1 \text { hari pada saat menurunkan } \\
\text { berat badan, } 22,22 \% \text { RAGU } \\
\text { RAGU,dan } 77,76 \% \text { TIDAK. }\end{array}$ \\
\hline 2 & $\begin{array}{l}\mathrm{SS}= \\
17 \% \\
\mathrm{~S}= \\
83 \% \\
\mathrm{RR}= \\
0 \% \\
\mathrm{TS} \\
=0 \% \\
\mathrm{STS} \\
=0 \%\end{array}$ & $\begin{array}{l}\text { Sebanyak } 100 \% \text { atlet } \\
\text { mengatakan YA bahwa dirinya } \\
\text { menjalani } 2 \text { kali latihan dalam } \\
1 \text { hari pada saat menurunkan } \\
\text { berat badan, } 0 \% \text { RAGU } \\
\text { RAGU,dan } 0 \% \text { TIDAK. }\end{array}$ \\
\hline 3 & $\begin{array}{l}\mathrm{SS}= \\
22 \% \\
\mathrm{~S}= \\
35 \% \\
\mathrm{RR}= \\
26 \% \\
\mathrm{TS} \\
=17 \% \\
\mathrm{STS} \\
=0 \%\end{array}$ & $\begin{array}{l}\text { Sebanyak 56,51 \% atlet } \\
\text { mengatakan YA bahwa } \\
\text { dirinya menjalani } 3 \text { kali } \\
\text { latihan dalam 1 hari pada saat } \\
\text { menurunkan berat badan, } \\
\text { 26,08 \% RAGU-RAGU, 17,39 } \\
\% \text { TIDAK. }\end{array}$ \\
\hline 4 & $\begin{array}{l}\mathrm{SS} \\
=67 \% \\
\mathrm{~S}=13 \\
\% \\
\mathrm{RR}= \\
20 \%\end{array}$ & $\begin{array}{l}\text { Sebanyak } 79,99 \% \text { atlet } \\
\text { mengatakan YA bahwa } \\
\text { pertandingan yang di ikutinya } \\
\text { di atas } 4 \text { kali pertahun, } 20 \% \\
\text { RAGU-RAGU, dan } 0 \% \\
\text { TIDAK. }\end{array}$ \\
\hline
\end{tabular}




\begin{tabular}{|c|c|c|}
\hline & $\begin{array}{l}\text { TS } \\
=0 \% \\
\text { STS } \\
=0 \%\end{array}$ & \\
\hline $\begin{array}{l}1 \\
5\end{array}$ & $\begin{array}{l}\mathrm{SS}= \\
34 \% \\
\mathrm{~S}= \\
55 \% \\
\mathrm{RR}= \\
14 \% \\
\mathrm{TS} \\
=0 \% \\
\mathrm{STS} \\
=0 \%\end{array}$ & $\begin{array}{l}\text { Sebanyak } 89,65 \% \text { atlet } \\
\text { mengatakan YA bahwa jadwal } \\
\text { pertandingan yang di ikutinya } \\
\text { terlalu padat dan mendadak, } \\
10,34 \% \text { RAGU-RAGU dan } 0 \\
\% \text { TIDAK. }\end{array}$ \\
\hline $\begin{array}{l}1 \\
6\end{array}$ & $\begin{array}{l}\mathrm{SS}= \\
48 \% \\
\mathrm{~S}= \\
52 \% \\
\mathrm{RR}= \\
0 \% \\
\mathrm{TS} \\
=0 \% \\
\mathrm{STS} \\
=0 \%\end{array}$ & $\begin{array}{l}\text { Sebanyak } 100 \% \text { atlet } \\
\text { mengatakan YA bahwa dirinya } \\
\text { makan besar sebanyak } 1 \\
\text { kali/hari pada saat } \\
\text { menurunkan berat badan,0 } \% \\
\text { RAGU-RAGU dan } 0 \% \\
\text { TIDAK. }\end{array}$ \\
\hline $\begin{array}{l}1 \\
7\end{array}$ & $\begin{array}{l}\mathrm{SS}= \\
0 \% \\
\mathrm{~S}= \\
0 \% \\
\mathrm{RR}= \\
21 \% \\
\mathrm{TS}= \\
28 \% \\
\mathrm{STS}= \\
52 \%\end{array}$ & $\begin{array}{l}\text { Sebanyak } 0 \text { \% atlet } \\
\text { mengatakan YA bahwa dirinya } \\
\text { makan besar sebanyak } 2 \\
\text { kali/hari pada saat penurunan } \\
\text { berat badan, } 20,68 \% \text { RAGU- } \\
\text { RAGU dan } 79,3 \% \text { TIDAK }\end{array}$ \\
\hline $\begin{array}{l}1 \\
8\end{array}$ & $\begin{array}{l}\mathrm{SS} \\
=0 \% \\
\mathrm{~S}= \\
0 \% \\
\mathrm{RR}= \\
10 \% \\
\mathrm{TS}= \\
40 \% \\
\mathrm{STS}= \\
50 \%\end{array}$ & $\begin{array}{l}\text { Sebanyak } 0 \% \text { mengatakan } \\
\text { YA bahwa dirinya makan } \\
\text { besar sebanyak } 3 \text { kali/hari } \\
\text { pada saat penurunan berat } \\
\text { badan, } 10 \% \text { RAGU-RAGU } \\
\text { dan } 90 \% \text { TIDAK. }\end{array}$ \\
\hline $\begin{array}{l}1 \\
9\end{array}$ & $\begin{array}{l}\mathrm{SS}= \\
38 \% \\
\mathrm{~S}= \\
46 \% \\
\mathrm{RR}= \\
0 \% \\
\mathrm{TS} \\
=15 \%\end{array}$ & $\begin{array}{l}\text { Sebanyak } 84,61 \% \text { atlet } \\
\text { mengatakan YA bahwa dirinya } \\
\text { menyukai minuman manis }, 0 \\
\% \text { RAGU-RAGU, } 15,38 \% \\
\text { TIDAK. }\end{array}$ \\
\hline
\end{tabular}

\begin{tabular}{lll}
\hline \multicolumn{3}{l}{ STS } \\
$=0 \%$
\end{tabular}

Tabel 6. Interpretasi Hasil Jawaban Tiap Indikator Pernyataan

\begin{tabular}{lllr}
\hline Dimensi & Indikator & \multicolumn{2}{l}{ Interpretasi } \\
\hline Atlet & Pengetah & $100 \%$ umumnya \\
& uan atlet & mengatakan YA \\
tentang & bahwa \\
ilmu gizi & pengetahuan \\
& (1) & tentang ilmu gizi \\
& yang di miliki oleh \\
& atlet tidak menjadi \\
& faktor penyebab \\
& masalah \\
& overweight dalam \\
& Jadi \\
& indikator ini \\
& tidak terjadi \\
& masalah yang \\
& menyebabkan \\
& overweight \\
\hline Disiplin & Pada umumnya \\
atlet & 72,54 \% atlet \\
dalam & mengatakan YA \\
menjaga & bahwa dirinya \\
berat & kurang disiplin \\
badan & dalam menjaga \\
& berat badan \\
& sehingga menjadi \\
\hline
\end{tabular}




\begin{tabular}{|c|c|c|}
\hline & & $\begin{array}{l}\text { salah satu faktor } \\
\text { penyebab } \\
\text { terjadinya } \\
\text { overweight. } \\
\text { Jadi, indikator } \\
\text { ini merupakan } \\
\text { salah satu faktor } \\
\text { penyebab } \\
\text { masalah } \\
\text { overweight }\end{array}$ \\
\hline & $\begin{array}{l}\text { Kepentin } \\
\text { gan atlet } \\
(4)\end{array}$ & $\begin{array}{l}\text { Pada umumnya } \\
\text { sebanyak } 7,69 \% \\
\text { atlet mengatakan } \\
\text { YA, bahwa } \\
\text { dirinya } \\
\text { mempunyai } \\
\text { kepentingan dalam } \\
\text { memilih kelas } \\
\text { sehingga menjadi } \\
\text { salah satu faktor } \\
\text { penyebab } \\
\text { terjadinya } \\
\text { overweight } \\
\text { Jadi, indikator } \\
\text { ini merupakan } \\
\text { salah satu faktor } \\
\text { penyebab } \\
\text { masalah } \\
\text { overweight }\end{array}$ \\
\hline Pelatih & $\begin{array}{l}\text { Perhatian } \\
\text { pelatih } \\
\text { dalam } \\
\text { mengontr } \\
\text { ol berat } \\
\text { badan } \\
(5,7)\end{array}$ & $\begin{array}{lr}\text { Pada umumnya } \\
\text { sebanyak 23,25\% } \\
\text { atlet mengatakan } \\
\text { YA } r \text { bahwa } \\
\text { perhatian pelatih } \\
\text { yang kurangdalam } \\
\text { mengontrol berat } \\
\text { badan } & \text { atlet } \\
\text { merupakan } & \text { salah } \\
\text { satu } & \text { faktor } \\
\text { penyebab } & \\
\text { terjadinya } & \\
\text { overweight. Jadi, } \\
\text { indikator } \\
\text { merupakan salah } \\
\text { satu } & \text { faktor } \\
\text { penyebab } & \\
\text { masalah } & \\
\text { overweight } & \end{array}$ \\
\hline & $\begin{array}{l}\text { Kepentin } \\
\text { gan } \\
\text { pelatih } \\
(6)\end{array}$ & $\begin{array}{l}\text { Pada umumnya } \\
\text { sebanyak } 81,76 \% \\
\text { atlet mengatakan } \\
\text { YA bahwa }\end{array}$ \\
\hline
\end{tabular}

\begin{tabular}{|c|c|c|}
\hline & & $\begin{array}{l}\text { kepentingan } \\
\text { pelatih merupakan } \\
\text { salah satu faktor } \\
\text { penyebab } \\
\text { terjadinya } \\
\text { overweight. Jadi, } \\
\text { indikator ini } \\
\text { merupakan salah } \\
\text { satu faktor } \\
\text { penyebab } \\
\text { masalah } \\
\text { overweight }\end{array}$ \\
\hline & $\begin{array}{l}\text { Aplikasi } \\
\text { Pengetah } \\
\text { uan } \\
\text { pelatih } \\
\text { tentang } \\
\text { ilmu gizi } \\
\text { dan } \\
\text { fisiologi } \\
\text { olahraga } \\
(8,9,10)\end{array}$ & $\begin{array}{lr}\text { Pada umumnya } \\
\text { sebanyak } 29,75 \% \\
\text { atlet mengatakan } \\
\text { YA bahwa } \\
\text { aplikasi } \\
\text { pengetahuan } \\
\text { pelatih yang } \\
\text { kurang tentang } \\
\text { ilmu gizi dan } \\
\text { fisiologi } \\
\text { merupakan salah } \\
\text { satu } \\
\text { penyebab faktor } \\
\text { terjadinya masalah } \\
\text { overweight. Jadi, } \\
\text { indikator } \\
\text { merupakan salah } \\
\text { satu faktor } \\
\text { penyebab } \\
\text { masalah } \\
\text { overweight }\end{array}$ \\
\hline \multirow[t]{2}{*}{$\begin{array}{l}\text { Program } \\
\text { latihan } \\
\text { dan } \\
\text { pertandin } \\
\text { gan }\end{array}$} & $\begin{array}{l}\text { Frekuensi } \\
\text { latihan } \\
\text { dalam } \\
\text { sehari } \\
(11,12,13 \\
)\end{array}$ & $\begin{array}{l}\text { Pada umumnya } \\
\text { sebanyak } 100 \% \\
\text { atlet mengatakan } \\
\text { YA bahwa } \\
\text { frekuensi latihan } \\
\text { yang } \\
\text { dilakukkannya } \\
\text { dalam } 1 \text { hari sudah } \\
\text { cukup dan tidak } \\
\text { menjadi penyebab } \\
\text { masalah } \\
\text { overweight } \\
\text { Jadi dalam } \\
\text { indikator ini } \\
\text { tidak terjadi } \\
\text { masalah yang } \\
\text { menyebabkan } \\
\text { overweight }\end{array}$ \\
\hline & Frekuensi & Pada umumnya \\
\hline
\end{tabular}




\begin{tabular}{|c|c|c|}
\hline & $\begin{array}{l}\text { pertandin } \\
\text { gan } \\
\text { dalam } \\
\text { setahun } \\
(14,15)\end{array}$ & $\begin{array}{l}\text { sebanyak } 84,73 \% \\
\text { atlet mengatakan } \\
\text { YA bahwa } \\
\text { frekuensi } \\
\text { pertandingan yang } \\
\text { padat } \\
\text { mendadak } \\
\text { merupakan salah } \\
\text { satu faktor } \\
\text { penyebab } \\
\text { terjadinya masalah } \\
\text { overweight . Jadi, } \\
\text { indikator } \\
\text { merupakan salah } \\
\text { satu faktor } \\
\text { penyebab } \\
\text { masalah } \\
\text { overweight }\end{array}$ \\
\hline \multirow[t]{2}{*}{$\begin{array}{l}\text { Pola } \\
\text { makan }\end{array}$} & $\begin{array}{l}\text { Frekuensi } \\
\text { makan } \\
\text { besar } \\
\text { dalam } \\
\text { satu hari } \\
\text { pada } \\
\text { masa pra } \\
\text { kompetisi } \\
\text { (16,17,18 } \\
\text { ) }\end{array}$ & $\begin{array}{l}\text { Pada umumnya } \\
\text { sebanyak } 100 \% \\
\text { atlet mengatakan } \\
\text { YA } \\
\text { frekuensi makan } \\
\text { besar yang di } \\
\text { lakukannya tidak } \\
\text { berlebihan dalam } \\
\text { satu hari } \\
\text { Jadi } \\
\text { indikator dalam } \\
\text { tidak ini } \\
\text { masalah terjadi } \\
\text { menyebabkan } \\
\text { overweight }\end{array}$ \\
\hline & $\begin{array}{l}\text { Asupan } \\
\text { kalori } \\
\text { yang } \\
\text { masuk } \\
\text { dalam } \\
\text { satu hari } \\
\text { pada } \\
\text { masa pra } \\
\text { kompetisi } \\
(22)\end{array}$ & $\begin{array}{l}\text { Pada umumnya } \\
\text { sebanyak } 100 \% \\
\text { atlet mengatakan } \\
\text { YA bahwa kalori } \\
\text { yang masuk } \\
\text { dalam satu hari ke } \\
\text { dalam dirinya } \\
\text { tidak berlebihan } \\
\text { Jadi dalam } \\
\text { indikator ini } \\
\text { tidak terjadi } \\
\text { masalah yang } \\
\text { menyebabkan } \\
\text { overweight }\end{array}$ \\
\hline $\begin{array}{l}\text { Pola } \\
\text { hidup }\end{array}$ & $\begin{array}{l}\text { Suka } \\
\text { makanan } \\
\text { berlemak } \\
\text { / ber- }\end{array}$ & $\begin{array}{l}\text { Pada umumnya } \\
\text { sebanyak } 83,33 \% \\
\text { atlet mengatakan } \\
\text { YA bahwa dirinya }\end{array}$ \\
\hline
\end{tabular}

\begin{tabular}{|c|c|}
\hline $\begin{array}{l}\text { santan } \\
(19)\end{array}$ & $\begin{array}{l}\text { suka makanan } \\
\text { yangberlemak/bers } \\
\text { antan dan menjadi } \\
\text { salah satu faktor } \\
\text { penyebab masalah } \\
\text { overweight. Jadi, } \\
\text { indikator ini } \\
\text { merupakan salah } \\
\text { satu faktor } \\
\text { penyebab } \\
\text { masalah } \\
\text { overweight }\end{array}$ \\
\hline $\begin{array}{l}\text { Suka } \\
\text { makanan } \\
\text { dan } \\
\text { minuman } \\
\text { yang } \\
\text { manis } \\
(20)\end{array}$ & $\begin{array}{l}\text { Pada umumnya } \\
\text { sebanyak } 84,61 \% \\
\text { atlet mengatakan } \\
\text { YA bahwa dirinya } \\
\text { suka makan } \\
\text { makanan dan } \\
\text { minum minuman } \\
\text { yang manis dan } \\
\text { menjadi salah satu } \\
\text { faktor penyebab } \\
\text { masalah } \\
\text { overweight. Jadi, } \\
\text { indikator ini } \\
\text { merupakan salah } \\
\text { satu faktor } \\
\text { penyebab } \\
\text { masalah } \\
\text { overweight }\end{array}$ \\
\hline
\end{tabular}

\section{KESIMPULAN}

Berdasarkan hasil penelitian maka peneliti menyimpulkan bahwa gambaran faktor-faktor penyebab masalah berat badan pada atlet pencak silat PPLP DKI Jakarta dan Ragunan pada masa kompetisi dilihat dari berbagai indikator yang ada, diantaranya sebagai berikut (a) Padatnya Frekuensi pertandingan dalam setahun sekitar 84,73\%, (b) Suka makanan dan minuman yang manis sekitar $84,61 \%$, (c) Suka makanan berlemak dan bersantan sekitar 83,33\%, (d) Kepentingan pelatih yang ingin menentukan sendiri kelas bagi atletnya sekitar 81,76\%, (e) Rendahnya Disiplin atlet dalam menjaga berat badan sekitar 72,54 \%, (e) Kurangnya Aplikasi pengetahuan pelatih tentang ilmu gizi dan fisiologi olahraga sekitar $29,75 \%$, (f) Kurangnya Perhatian pelatih dalam mengontrol berat badan sekitar 23,25\%, (g) 
kepentingan atlet yang ingin menentukan kelasnya sendiri sekitar 7,69\%.

\section{SARAN}

Setelah menyimpulkan dari hasil penelitian, peneliti ingin menyampaikan saran-saran sebagai berikut

a. Pelatih dan pengurus harus mempunyai target utama perihal tujuan menyertakan atletnya dalam suatu kejuaraan,

b. Hal yang harus dihindari yaitu pertandingan yang diikuti atlet terlalu padat dan mendadak, karena kondisi ini akan membuat atlet tidak nyaman bagi atlet yang mengalami masalah overweight,

c. Diharapkan atlet lebih mengontrol pola makan terkait kebiasaan atlet yang suka makanan dan minuman yang manis, makanan berlemak karena hal seperti ini jika dikonsumsi secara berlebihan akan berdampak pada berat badan atlet yang meningkat (makanan manis banyak mengandung glukosa),

d. Dalam penentuan kelas dalam pertandingan sebaiknya pelatih jangan menentukannya sendiri, lebih baik penentuan kelas dalam pertandingan ditentukan oleh atlet, pelatih hanya memberi pandangan-pandangan terkait hal ini, sehingga atlet merasa nyaman jika bertanding sesuai kemauan dan berat badannya masing-masing,

e. Dalam pengontrolan berat badan, sebaiknya pada masa persiapan umum berat badan atlet harus sudah masuk sesuai kriteria berat badan yang akan diikutinya nanti, dalam hal ini komitmen atlet dalam mengontrol berat badan sangat diutamakan, selain itu peran pelatih dalam memonitor berat badan atlet juga sangat di perlukan, jangan sampai pelatih mengontrol berat badan atlet pada masa 2 minggu menjelang pertandingan, karena masalah ini lah yang sering kali terjadi f. Perlu diintensifkannya penataran pelatih tentang ilmu gizi dan fisiologi olahraga, sehingga pelatih lebih menguasai tentang permasalahan yang sehari - hari terjadi berkaitan tentang kebutuhan atlet akan penerapan ilmu gizi dan fisiologi olahraga,

g. Merubah pemahaman para pelaku kegiatan olahraga pencak silat ini ( pelatih, atlet, dan ahli gizi ) terutama tentang konsep pengaturan pola makan dan pengaturan berat badan pada sistem periodesasi latihan, (h) Atlet harus berkomitmen untuk bertanding sesuai dengan kelas berdasarkan berat badannya karena jika atlet bertanding tidak sesuai dengan kondisinya akan memperburuk kondisi fisik yang menyebabkan prestasi tidak maksimal,

h. Untuk menurunkan berat badan yang terakhir gunakan diet rendah sisa pada beberapa hari menjelang pertandingan. Cara yang paling mudah adalah mengganti makanan padat dengan makanan cair. Makanan jenis ini akan menyediakan karbohidrat untuk simpanan otot dan zat gizi yang lain, namun membiarkan saluran cerna kosong dan ringan,

i. Jika memang terpaksa bertanding di kelas yang bukan merupakan berat ideal atlet, yang harus dilakukan yaitu selalu mengontrol berat badan atlet dan menjaga pola makan yang ideal. Selain itu prinsip yang harus diperhatikan untuk merubah berat badan tidak bisa dilakukan secara instan. Merubah berat badan harus dilakukan jauh hari sebelum pertandingan dilaksanakan karena jika dipaksakan secara instan akan berdampak pada hasil pertandingan dan kondisi fisik yang sangat riskan. 


\section{DAFTAR PUSTAKA}

Ganong, William F.MD. Fisiologi Kedokteran. EGC Penerbit Buku Kedokteran, (di terjemahkan Adji Dharma, 2003).

Hiromi Shinya,M.D. The miracle of Enzyme. (Bandung: PT. Mizan Pustaka,2008).

Lubis, Johansyah, Pencak Silat Panduan Praktis (Jakarta : Raja Grafindo Persada 2004)

M. Otok Iskandar dan Soemardjono, Pencak Silat,(Departemen Pendidikan dan Kebudayaan Direktorat Jendral Pendidikan Tinggi, 1992)

Notosoejitno, Khazanah Pencak Silat, (Jakarta : Sagung Seto, 1997 )

O’ong Maryono, Pencak Silat Merentang Waktu, (Yogyakarta : Galang Press, 1999 )

Sugiyono. Metode Penelitian Administrasi. (Bandung, Alfabeta:2007),

Suharsimi Arikunto, Manajemen Penelitian. (Jakarta : Rineka Cipta, 1995)

Sukadji, Soetarlinah. Menyusun dan Mengevaluasi Laporan Penelitian, (Jakarta : UI-Press, 2000).

Sunita Almatsier. Prinsip Dasar Ilmu Gizi. (Jakarta: Gramedia Pustaka Utama, 2001) 